\title{
Josef se Gebeente.
}

MARTIN MEERMAN.

-

Daar trek die slawevolk, verlos deur wonderdade, die wye ruimtes in, met skatte ryk belade.

Die weg is ongebaan, die dors laat hul verkwyn, en voor hul-eindeloos'n dorre sandwoestyn.

Oorwinnend gaan hul na

hul land, die lank beloofde.

'n Konings-sarkofaag

is sigbaar oor hul hoofde.

Die dor gebeente wat

hul skouers onderskraag.

Simbool slegs van die dood

is hierdie sarkofaag.

Die sarkofaag besiel; -

voort trek die groot gemeente!

Die rus is voorbeskik

vir húl-en dié gebeente;

dit was profetewoord,

die sarkofaag is pand

en 'n getuienis:

Hul wag 'n vaderland.

So is die volk op trek, die Godsvolk al die tye.

Hul dra ' $n$ onderpand

- met innig sielsverblye-

'n waarborg waar hul gaan:

hoe troosteloos die reis,

die einde is die rus,

hul wag die Paradys. 